\title{
Life satisfaction of the pregnant women
}

\author{
Satysfakcka zizycia kobiet cięarnych
}

\author{
Agnieszka Skurzak', Marta Zarajczyk', Grażyna Iwanowicz-Palus', \\ Magdalena Korżyńska-Piętas', Magdalena Lewicka², Henryk Wiktor²
}

'Zakład Podstaw Położnictwa, Wydział Nauk o Zdrowiu Uniwersytet Medyczny w Lublinie/ Department of the Basics of Midwifery, Faculty of Health Sciences, Medical University of Lublin 2Zakład Położnictwa, Ginekologii i Pielęgniarstwa Położniczo-Ginekologicznego, Wydział Nauk o Zdrowiu Uniwersytet Medyczny w Lublinie/ Department of Obstetrics, Gynaecology and Obstetric-Gynaecological Nursing Faculty of Health Sciences, Medical University of Lublin

Grażyna Iwanowicz-Palus: 0000-0002-1617-4764 Henryk Wiktor: 0000-0002-4026-1884 Agnieszka Skurzak: 0000-0001-6846-4395

CORRESPONDING AUTHOR/AUTOR DO KORESPONDENCJ: Agnieszka Skurzak Zakład Podstaw Położnictwa, Wydział Nauk o Zdrowiu Uniwersytet Medyczny w Lublinie ul. Staszica 4/6, 20-081 Lublin e-mail: agnieszka.skurzak@umlub.pl

\section{STRESZCZENIE SATYSFAKCJA ZŻYCIA KOBIET CIEZZARNYCH}

Wprowadzenie. Satysfakcja z życia to ogólna ocena zadowolenia z własnych osiągnięći warunków życia na wielu jego płaszczyznach. Obejmuje procesy poznawcze człowieka, wyrażające stan emocjonalny występujący na skutek osiągnięcia określonego celu. Według Juczyńskiego ocena satysfakcji z życia jest efektem konfrontacji własnej sytuacji z przyjętymi kryteriami. Jeśli wynik porównania jest pozytywny to jego implikacją jest odczucie satysfakcji. Satysfakcja zżycia kobiet ciężarnych jest zależna od wielu czynników min. od: cech osobowości, emocji, czynników socjodemograficznych, a także licznych zmian natury fizjologicznej i psychologicznej zachodzących podczas ciąży.

Cel pracy. Celem badań jest ocena poziomu satysfakcji z życia kobiet ciężarnych w zależności od czynników socjodemograficznych. Materiał i metody. Badania zostały przeprowadzone wśród 415 ciężarnych hospitalizowanych i korzystających z opieki w poradniach dla kobiet ciężarnych. Badania przeprowadzono metodą sondażu diagnostycznego z wykorzystaniem standaryzowanej Skal Satysfakcji zŻycia (Satisfaction With Life Scale - SWLS) i autorskiego kwestionariusza ankiety w celu zgromadzenia danych demograficznych. Wyniki. Na podstawie średniej oceny satysfakcji z życia stwierdzono, że 48,43\% ( $n=201)$ badanych ciężarnych cechował wysoki stopień satysfakcji z życia, 35,18\% ( $n=146$ ) przeciętny, zaś 16,39\% ( $n=68)$ badanych odczuwało niski poziom satysfakcji z życia.

Wnioski. Czynniki socjodemograficzne warunkowały poczucie satysfakcji z życia kobiet w ciąży. Większe poczucie satysfakcji z życia miały ciężarne będące w związku aniżeli ciężarne samotne; kobiety z wykształceniem wyższym aniżeli posiadające wykształcenie podstawowe lub zawodowe oraz średnie; ciężarne pracujące umysłowo aniżeli nie pracujące.

Słowa kluczowe: ciąża, satysfakcja z życia, czynniki socjodemograficzne

Introduction. Satisfaction with life is a general assessment of satisfaction with one's own achievements and living conditions on many levels. This includes human cognitive processes, expressing the emotional state that occurs as a result of achieving a specific goal. According to Juczyński, the assessment of life satisfaction is the result of confronting one's own situation with the adopted criteria. If the result of the comparison is positive, the implication is the feeling of satisfaction. Satisfaction with life of pregnant women is dependent on many factors, including: personality traits, emotions, sociodemographic, factors as well as numerous physiological and psychological changes occurring during pregnancy.

Aim. The aim of the study is to assess the level of life satisfaction of pregnant women depending on sociodemographic factors.

Material and methods. The research was conducted on 415 women hospitalized and receiving care in counseling centers for pregnant women. The research was carried out by means of a diagnostic survey using a standardized Satisfaction With Life Scale (SWLS) and an original questionnaire to collect demographic data.

Results. Based on the average assessment of life satisfaction, it was found that $48.43 \%(n=201)$ of the surveyed pregnant women was characterized by a high degree of life satisfaction, $35.18 \%(n=146)$ average, and $16.39 \%(n=68)$ of the respondents experienced a low level of life satisfaction.

Conclusions. Sociodemographic factors conditioned the feeling of satisfaction with life of pregnant women. Pregnant women who had a greater sense of life satisfaction were: those in relationship rather than those who were single; women with higher education than those with basic, vocational or secondary education; pregnant women working mentally rather than those not working. 


\section{INTRODUCTION}

Satisfaction with life includes human cognitive processes, expressing the emotional state that occurs as a result of achieving a specific goal. According to Juczyński, the assessment of life satisfaction is the result of confronting one's own situation with the adopted criteria. If the result of the comparison is positive, its implication is the feeling of satisfaction [1]. Satisfaction with life is experienced in a unique way by each person and depends on the personality traits, individual resources, external factors, living conditions and life events and their interaction [2]. Pregnancy is a period characterized by a changeable emotional state, from the joy of waiting for the birth of a child, to the occurrence of fears related to the course of pregnancy and childbirth [3]. Studies have shown that during pregnancy, women's life satisfaction increases, while in the first years of motherhood, the level of life satisfaction decreases to the level of prior pregnancy $[4,5,6]$. As it can be seen from the literature, the satisfaction with life of pregnant women is dependent on temperament, variable emotions, received social support, partner, sociodemographic factors and endocrine, physical and psychological changes occurring in individual trimesters of pregnancy $[4,7,8,9,10]$.

\section{AIM}

The aim of the study is to assess the relationship between life satisfaction of pregnant women and sociodemographic factors.

\section{MATERIALS AND METHODS}

The study conducted from July 2014 to October 2015 covered 415 pregnant women hospitalized and treated in Lublin hospitals, as well as those receiving care at the Pregnant Women's Outpatient Clinic in Lublin. The examined pregnant women volunteered to complete the questionnaire, after being informed that the research results were to be used only for scientific purposes, and to ensure anonymity. In the case of examined pregnant minors, the consent of the guardian was obtained. The approval of the Bioethics Committee at the Medical University in Lublin, no. KE-0254/179/2014, was obtained for the tests. The research was carried out by means of a diagnostic survey using a standardized Satisfaction With Life Scale (SWLS) to assess the sense of life satisfaction. The scale is used to assess the sense of life satisfaction, it is intended for the examination of adults, both healthy and the sick ones. This tool consists of 5 statements assessed on a seven-level scale. The ratings after summing up give the total result, which is determined in the range from 5 to 35 points. The higher the score, the greater the sense of life satisfaction. In the interpretation of the result on the sten scale, the values in the range from 1st to 4 th sten are treated as low scores, in the 5 th and 6 th sten ranges as average, and in the range from $7^{\text {th }}$ to $10^{\text {th }}$ sten - as high. In addition, a questionnaire was created for specific study of the pregnant women. Obtained results of the study were subjected to statistical analysis. The database and statistical surveys based on STATISTICA 9.1 computer software (StatSoft, Poland). The values of the measurable parameters analyzed were presented using the mean value and standard deviation, and for non-measurable ones - with the help of cardinality and percentage. For measurable features, the normality of the distribution of the analyzed parameters was evaluated using the Shapiro-Wilk test. A significance level of $\mathrm{p}<0.05$ was assumed indicating the existence of statistically significant differences or dependencies.

\section{RESULTS}

In the pregnant group under study, 34.94\% $(\mathrm{n}=145$; $)$ were aged $26-30,31.08 \%(n=129)$, aged $31-35$. In contrast, $2.17 \%(n=9)$ were pregnant over 40 years and $0.72 \%(n=3)$ pregnant under 18 years of age. Based on the collected data, it was found that the majority of the respondents were married $84.4 \%(n=349)$, and $7.95 \%(n=33)$ were women in an informal relationship, while $6.75 \%(\mathrm{n}=28)$ was single and $1.20 \%(n=5)$ - divorcees. In the study group, the majority of the pregnant dwelled in the provincial city $40.96 \%$ $(\mathrm{n}=170)$ and the district town $22.17 \%(\mathrm{n}=92)$, and $36.87 \%$ ( $n=153$ ) of the pregnant lived in the country. The majority of respondents had a higher education level $65.78 \%$ $(\mathrm{n}=273)$, and secondary education was declared by $25.06 \%$ $(\mathrm{n}=104)$, while vocational education by $5.78 \%(\mathrm{n}=24)$ and primary education by $3.37 \%(n=14)$ of the surveyed women. In the group of pregnant women under study 224 (53.98\%) worked mentally, 83 (20.0\%) did not work professionally or physically. Only 25 (6.02\%) were students.

Tab. 1. Socio-demographic characteristics of pregnant women in the study

\begin{tabular}{|c|c|c|c|}
\hline \multicolumn{2}{|c|}{ Socio-demographic factors } & $\mathrm{N}$ & $\%$ \\
\hline \multirow{7}{*}{ Age } & below18 years of age & 3 & 0.72 \\
\hline & $18-20$ years of age & 12 & 2.89 \\
\hline & $21-25$ years of age & 70 & 16.87 \\
\hline & $26-30$ years of age & 145 & 34.94 \\
\hline & $31-35$ years of age & 129 & 31.08 \\
\hline & $36-40$ years of age & 47 & 11.33 \\
\hline & over 40 years of age & 9 & 2.17 \\
\hline \multirow{5}{*}{ Marital status } & single & 28 & 6.75 \\
\hline & married & 349 & 84.10 \\
\hline & widow & 0 & 0.00 \\
\hline & divorcee & 5 & 1.20 \\
\hline & informal relationship & 33 & 7.95 \\
\hline \multirow{3}{*}{ Dwelling place } & provincial city & 170 & 40.96 \\
\hline & district town & 92 & 22.17 \\
\hline & country & 153 & 36.87 \\
\hline \multirow{4}{*}{ Education level } & primary & 14 & 3.37 \\
\hline & vocational & 24 & 5.78 \\
\hline & secondary & 104 & 25.06 \\
\hline & higher & 273 & 65.78 \\
\hline \multirow{4}{*}{ Professional status } & not working & 83 & 20.00 \\
\hline & physical work & 83 & 20.00 \\
\hline & mental work & 224 & 53.98 \\
\hline & student & 25 & 6.02 \\
\hline
\end{tabular}


Based on the average assessment of life satisfaction, it was found that $48.43 \%(\mathrm{n}=201)$ of the surveyed pregnant women was characterized by a high degree of life satisfaction, $35.18 \%(n=146)$ by average, and $16.39 \%$ $(n=68)$ of the respondents - low level of life satisfaction. The results of the general study on the life satisfaction of pregnant women are presented in Table 2.

Tab. 2. General results of life satisfaction survey of pregnant women

\begin{tabular}{|l|c|c|c|}
\hline \multicolumn{2}{|c|}{ General results } & N & $\%$ \\
\hline \multirow{3}{*}{ SWLS level } & low & 68 & 16.39 \\
\cline { 2 - 4 } & average & 146 & 35.18 \\
\cline { 2 - 4 } & high & 201 & 48.43 \\
\hline
\end{tabular}

The mean value of life satisfaction (SWLS) in the group of women in the relationship was 23.05 and was significantly higher than 20.58 in the group of single women $(\mathrm{p}=0.013)$. Statistical analysis showed that marital status conditioned the life satisfaction of the respondents, which was higher in the group of married pregnant women than in the unmarried pregnant women. The analysis of the life satisfaction assessment depending on marital status is presented in Table 3.

Tab. 3. Interdependence between life satisfaction and marital status of pregnant subjects

\begin{tabular}{|l|c|c|c|c|c|c|c|c|}
\hline \multirow{2}{*}{$\begin{array}{c}\text { Analyzed } \\
\text { variable }\end{array}$} & \multicolumn{7}{|c|}{ Unmarried } & \multicolumn{3}{c|}{ Married } & \multirow{2}{*}{$\mathbf{Z}$} & \multirow{2}{*}{$\mathbf{p}$} \\
\cline { 2 - 7 } & $\mathbf{M}$ & Me & SD & M & Me & SD & & \\
\hline $\begin{array}{l}\text { Life satisfaction } \\
\text { indicator }\end{array}$ & 20.58 & 20.00 & 5.96 & 23.05 & 23.50 & 5.66 & 2.492 & 0.013 \\
\hline
\end{tabular}

The mean value of life satisfaction (SWLS) in the group of respondents with higher education was 23.75 and was significantly higher $(\mathrm{p}=0.0001)$ than 20.97 in the group of pregnant women with elementary / vocational education, and significantly higher $(\mathrm{p}=0.0001)$ related to 21.17 in the group of pregnant women with secondary education. The comparative analysis did not show significant differences between the obtained mean values in the group of women with elementary or vocational and secondary education $(p \geq 0.05)$. The research shows that women who had higher education level experienced significantly better

Tab. 4. Interdependence between life satisfaction and education of pregnant women

\begin{tabular}{|c|c|c|c|c|c|c|c|c|c|c|c|}
\hline \multirow{3}{*}{$\begin{array}{c}\text { Analyzed } \\
\text { variable }\end{array}$} & \multicolumn{11}{|c|}{ Education level } \\
\hline & \multicolumn{3}{|c|}{$\begin{array}{l}\text { elementary/ } \\
\text { vocational }\end{array}$} & \multicolumn{3}{|c|}{ secondary } & \multicolumn{3}{|c|}{ higher } & \multirow{2}{*}{ Z } & \multirow{2}{*}{$\mathbf{p}$} \\
\hline & $M$ & Me & SD & $M$ & $\mathrm{Me}$ & SD & M & $\mathrm{Me}$ & SD & & \\
\hline $\begin{array}{l}\text { Life satisfaction } \\
\text { indicator }\end{array}$ & 20.97 & 22.00 & 6.42 & 21.17 & 22.00 & 5.45 & 23.75 & 24.00 & 5.53 & 19.737 & 0.0001 \\
\hline
\end{tabular}

life satisfaction than women with basic or vocational or secondary education. Therefore, education was a factor conditioning the satisfaction of the subjects' life. The assessment of life satisfaction of pregnant women depending on their education is presented in Table 4.

Research has shown that professional status conditioned the satisfaction of life of the surveyed women. The mean value of life satisfaction (SWLS) in the group of mental workers was 23.81 , and was significantly higher than 20.55 in the group of no working pregnant women $(p=0.0001)$. The analysis of the assessment of life satisfaction of pregnant women depending on their professional status is presented in Table 5 .

\section{DISCUSSION}

The objective of the presented study was to determine the level of satisfaction with life of pregnant women depending on sociodemographic factors. The results of our own research showed that $48.43 \%$ of pregnant women was characterized by a high level of life satisfaction, $35.18 \%$ with the average one, and $16.39 \%$ of respondents - with low level of life satisfaction. Research carried out in 2018 by the Center for Social Opinion Research shows that $76 \%$ of Poles declares satisfaction with their life [11]. On the basis of own research, it was found that marital status conditioned satisfaction with life. Głębocka and Sarzyńska (2005), in studies conducted in the group of elderly people, assessed life satisfaction depending on marital status. Authors' research shows that people who had a spouse were happier and presented a higher level of satisfaction with life than others (bachelors, maids, widowers, widows, living in an informal relationship) [12]. Similar results were obtained by Wysokiński et al. (2009), in studies carried out in the group of nurses. The analysis of these authors' research shows that marital status was significant for the level of satisfaction with life. The married and widowed people evaluated the best life satisfaction. Divorcees assessed the level of life satisfaction as average, while the unmarried people rated the worst their level of life satisfaction [13]. Whereas Kowalczyk and Rzepa (2015), analyzing 123 women, aged from 20 to 60 years, showed that women in a permanent relationship felt greater satisfaction with life than those not remaining in a relationship [14]. Kanadys et al. (2015), as well as Kazimierczak et al. (2018) showed that the marital status of the pregnant subjects conditioned their satisfaction with life, which was higher in the group of married women than lonely women $[15,16]$. Our own research remains in compliance with the research of the above authors. Own research

Tab. 5. Interdependence between life satisfaction and professional status

\begin{tabular}{|c|c|c|c|c|c|c|c|c|c|c|c|c|c|c|}
\hline \multirow{3}{*}{ Analyzed variable } & \multicolumn{14}{|c|}{ Professional status } \\
\hline & \multicolumn{3}{|c|}{ does not work } & \multicolumn{3}{|c|}{ physical work } & \multicolumn{3}{|c|}{ mental work } & \multicolumn{3}{|c|}{ student } & \multirow{2}{*}{$\mathbf{Z}$} & \multirow{2}{*}{$\mathbf{p}$} \\
\hline & M & Me & SD & M & $\mathrm{Me}$ & SD & M & Me & SD & M & $\mathrm{Me}$ & SD & & \\
\hline Life satisfaction indicator & 20.55 & 21.00 & 5.92 & 22.96 & 23.00 & 5.16 & 23.81 & 24.00 & 5.66 & 21.56 & 22.00 & 5.24 & 22.453 & 0.0001 \\
\hline
\end{tabular}


shows that marital status conditioned life satisfaction of pregnant women, which was significantly higher in the group of married pregnant women than in the group of single women $(\mathrm{p}<0.013)$. In the literature on the subject, there are reports indicating the diversity of the level of life satisfaction depending on the education of the surveyed respondents. Own research showed that education conditioned the satisfaction of life of pregnant women, which was higher in the group of women with higher education $(M=23.75)$ than in the group of subjects with basic or vocational education $(M=20.97)$, and medium $(\mathrm{M}=21.17)$. Kanadys et al. (2015), basing on the results of their own research, found that pregnant women with higher education experienced higher life satisfaction than pregnant women with secondary, primary or vocational education [15]. Assessment of life satisfaction among women in perimenopausal age made by Kanadys et al. (2014) confirmed the thesis that the level of education conditioned life satisfaction, which was higher in the group of women with higher education than in the group of subjects with secondary and basic education or vocational one [17]. Satisfaction with one's professional status was another aspect conditioning the life satisfaction of the pregnant women surveyed. Our own research showed that occupational status conditioned the satisfaction of life of pregnant women. The average life satisfaction value (SWLS) in the group of mental workers was 23.81 and was significantly higher $(\mathrm{p}=0.0001)$ than 20.55 in the group of pregnant women not working. According to the Center for Public Opinion Research of 2017, 50\% of respondents was satisfied with the course of their professional work [11]. Studies by Czarnecka et al. (2012), and Banaczek and Saracen (2016), conducted among women in perimenopausal period confirm the thesis that occupational status correlated positively with the results of life satisfaction $[18,19]$. Similar results were obtained by Irfan et al. (2012), conducting research among 90 women aged between 25 and 36 years. Individuals who rated their professional status higher, scored higher on the scale of life satisfaction [20].

\section{CONCLUSIONS}

The studied sample presented a high level of life satisfaction. Marital status, education and professional status significantly differentiate the degree of life satisfaction in pregnant women.

\section{Satysfakcja z życia kobiet ciężarnych}

\section{WPROWADZENIE}

Satysfakcja z życia obejmuje procesy poznawcze człowieka, wyrażające stan emocjonalny występujący na skutek osiągnięcia określonego celu. Według Juczyńskiego ocena satysfakcji z życia jest efektem konfrontacji własnej sytuacji z przyjętymi kryteriami. Jeśli wynik porównania jest pozytywny to jego implikacją jest odczucie satysfakcji [1]. Satysfakcja z życia jest doświadczana w sposób niepowtarzalny przez każdą osobę i zależy od cech osobowości, zasobów jednostki, czynników zewnętrznych, warunków życia i zdarzeń życiowych oraz ich interakcji [2].

Ciąża jest okresem charakteryzującym się zmiennym stanem emocjonalnym, od radości oczekiwania na narodziny dziecka, po występowanie lęków związanych z przebiegiem ciąży, porodu [3]. Badania wykazały, że podczas ciąży zwiększa się odczuwanie przez kobiety satysfakcji z życia, natomiast $\mathrm{w}$ pierwszych latach macierzyństwa poziom satysfakcji z życia obniża się do stanu sprzed ciąży $[4,5,6]$.

Jak wynika $\mathrm{z}$ piśmiennictwa satysfakcja $\mathrm{z}$ życia kobiet ciężarnych jest zależna od temperamentu, zmiennych emocji, otrzymywanego wsparcia społecznego, stosunków partnerskich czynników socjodemograficznych oraz zmian endokrynologicznych, fizycznych i psychologicznych zachodzące w poszczególnych trymestrach ciąży $[4,7,8,9,10]$.

\section{CEL PRACY}

Celem badań jest ocena związku pomiędzy satysfakcją z życia kobiet ciężarnych a czynnikami socjodemograficznymi.

\section{MATERIAŁ I METODYKA}

Badaniami objęto 415 kobiet ciężarnych, od lipca 2014 roku do października 2015 roku, hospitalizowanych i leczonych w lubelskich szpitalach, a także korzystających z opieki w Poradniach dla Kobiet Ciężarnych w Lublinie. Badane wyraziły dobrowolną zgodę na wypełnienie ankiety, po uprzednim poinformowaniu o wykorzystaniu wyników badań wyłącznie do celów naukowych, oraz zapewnieniu o anonimowości. W przypadku badanych ciężarnych niepełnoletnich pozyskano zgodę opiekuna.

$\mathrm{Na}$ przeprowadzenie badań uzyskano zgodę Komisji Bioetycznej przy Uniwersytecie Medycznym w Lublinie, Nr KE-0254/179/2014. Badania przeprowadzono metodą sondażu diagnostycznego $\mathrm{z}$ wykorzystaniem standaryzowanej Skali Satysfakcji z Życia (Satisfaction With Life Scale - SWLS) do oceny poczucia zadowolenia z życia. Skala służy do oceny poczucia zadowolenia z życia, przeznaczona jest do badania osób dorosłych, zarówno zdrowych, jak i chorych. Narzędzie to składa się z 5 stwierdzeń ocenianych w skali siedmiostopniowej. Oceny po zsumowaniu dają ogólny wynik, który oznacza się w granicach od 5 do 35 punktów. Im wyższy wynik, tym większe poczucie satysfakcji z życia. W interpretacji wyniku w skali stenowej wartości w granicach od 1. do 4. stena traktowane są jako wyniki niskie, w granicach 5. i 6. stena, jako przeciętne, zaś w granicach od 7. do 10. stena, jako wysokie.

Dodatkowo stworzono kwestionariusz własnego autorstwa opracowany do ustalenia charakterystyki badanych kobiet ciężarnych. 
Uzyskane wyniki badań poddano analizie statystycznej. Bazę danych i badania statystyczne przeprowadzono w oparciu o oprogramowanie komputerowe STATISTICA 9.1 (StatSoft, Polska). Wartości analizowanych parametrów mierzalnych przedstawiono przy pomocy wartości średniej i odchylenia standardowego, a dla niemierzalnych przy pomocy liczności i odsetka. Dla cech mierzalnych normalność rozkładu analizowanych parametrów oceniano przy pomocy testu W Shapiro-Wilka. Przyjęto poziom istotności $\mathrm{p}<0,05$ wskazujący na istnienie istotnych statystycznie różnic bądź zależności.

\section{WYNIKI}

W badanej grupie ciężarnych $34,94 \%(n=145 ;)$ było w wieku 26-30 lat, 31,08\% ( $n=129)$ było w wieku 31-35 lat. Natomiast $2,17 \%(\mathrm{n}=9)$ stanowiły ciężarne w wieku ponad 40 lat i 0,72\% $(n=3)$ ciężarne $\mathrm{w}$ wieku poniżej 18 lat.

$\mathrm{Na}$ podstawie zebranych danych stwierdzono, iż ankietowane w większości były mężatkami 84,10\% (n=349), zaś $7,95 \%(n=33)$ to kobiety będące $\mathrm{w}$ związku nieformalnym: $6,75 \%(n=28)$ panny oraz $1,20 \%(n=5)$ rozwódki.

$\mathrm{W}$ badanej grupie najwięcej ciężarnych zamieszkiwało miasto wojewódzkie $40,96 \%(n=170)$ i miasto powiatowe $22,17 \%$ ( $n=92)$, zaś 36,87\% ( $n=153$ ) ciężarnych mieszkało na wsi.

W większości badane posiadały wykształcenie wyższe $65,78 \%(n=273)$, zaś wykształcenie średnie deklarowało $25,06 \%(n=104)$, z kolei wykształcenie zawodowe posiadało $5,78 \%(n=24)$ a wykształcenie podstawowe posiadało $3,37 \%(n=14)$ badanych kobiet.

\section{Tab. 1. Charakterystyka społeczno-demograficzna badanych}

\begin{tabular}{|c|c|c|c|}
\hline \multicolumn{2}{|c|}{ Czynniki społeczno-demograficzne } & \multirow{2}{*}{$\begin{array}{c}\mathbf{N} \\
3\end{array}$} & \multirow{2}{*}{$\begin{array}{c}\% \\
0,72\end{array}$} \\
\hline \multirow{7}{*}{ Wiek } & poniżej 18 r.ż. & & \\
\hline & $18-20$ lat & 12 & 2,89 \\
\hline & 21-25 lat & 70 & 16,87 \\
\hline & $26-30$ lat & 145 & 34,94 \\
\hline & 31-35 lat & 129 & 31,08 \\
\hline & $36-40$ lat & 47 & 11,33 \\
\hline & ponad 40 lat & 9 & 2,17 \\
\hline \multirow{5}{*}{ Stan cywilny } & panna & 28 & 6,75 \\
\hline & mężatka & 349 & 84,10 \\
\hline & wdowa & 0 & 0,00 \\
\hline & rozwiedziona & 5 & 1,20 \\
\hline & związek nieformalny & 33 & 7,95 \\
\hline \multirow{3}{*}{ Miejsce zamieszkania } & miasto wojewódzkie & 170 & 40,96 \\
\hline & miasto powiatowe & 92 & 22,17 \\
\hline & wieś & 153 & 36,87 \\
\hline \multirow{4}{*}{ Wykształcenie } & podstawowe & 14 & 3,37 \\
\hline & zasadnicze zawodowe & 24 & 5,78 \\
\hline & średnie & 104 & 25,06 \\
\hline & wyższe & 273 & 65,78 \\
\hline \multirow{4}{*}{ Status zawodowy } & nie pracuję zawodowo & 83 & 20,00 \\
\hline & praca fizyczna & 83 & 20,00 \\
\hline & praca umysłowa & 224 & 53,98 \\
\hline & uczeń / student & 25 & 6,02 \\
\hline
\end{tabular}

W grupie badanych ciężarnych 224 (53,98\%) pracowały umysłowo, 83 (20,0\%) nie pracowały zawodowo bądź pracowały fizycznie. Jedynie $25(6,02 \%)$ było uczennicami lub studentkami.

Na podstawie średniej oceny satysfakcji z życia stwierdzono, że 48,43\% (n=201) badanych ciężarnych cechował wysoki stopień satysfakcji z życia, 35,18\% (n=146) przeciętny, zaś $16,39 \%(n=68)$ badanych - niski poziom satysfakcji z życia.

Wyniki ogólne badania satysfakcji z życia kobiet ciężarnych przedstawiono w tabeli 2 .

- Tab. 2. Wyniki ogólne badania satysfakcji z życia ciężarnych

\begin{tabular}{|c|c|c|c|}
\hline \multicolumn{2}{|c|}{ Wyniki ogólne } & N & $\%$ \\
\hline \multirow{3}{*}{ Poziom SWLS } & niski & 68 & 16,39 \\
\cline { 2 - 4 } & przeciętny & 146 & 35,18 \\
\cline { 2 - 4 } & wysoki & 201 & 48,43 \\
\hline
\end{tabular}

Średnia wartość satysfakcji z życia (SWLS) w grupie kobiet będących w związku wynosiła 23,05 i była istotnie większa od wynoszącej 20,58 w grupie kobiet samotnych $(\mathrm{p}=0,013)$. Analiza statystyczna wykazała, że stan cywilny warunkował satysfakcję z życia badanych, która była większa w grupie ciężarnych będących w związku aniżeli ciężarnych samotnych. Analizę oceny satysfakcji z życia w zależności od stanu cywilnego przedstawiono w tabeli 3 .

Tab. 3. Współzależność pomiędzy satysfakcją z życia a stanem cywilnym badanych

\begin{tabular}{|c|c|c|c|c|c|c|c|c|}
\hline \multirow{3}{*}{$\begin{array}{c}\text { Analizowana } \\
\text { zmienna }\end{array}$} & \multicolumn{8}{|c|}{ Stan cywilny } \\
\hline & \multicolumn{3}{|c|}{ Wolny } & \multicolumn{3}{|c|}{ Zamężny } & \multirow{2}{*}{ Z } & \multirow{2}{*}{ p } \\
\hline & $M$ & Me & SD & M & Me & SD & & \\
\hline $\begin{array}{l}\text { Wskaźnik } \\
\text { satysfakcji } \\
\text { zżycia }\end{array}$ & 20,58 & 20,00 & 5,96 & 23,05 & 23,50 & 5,66 & 2,492 & 0,013 \\
\hline
\end{tabular}

Średnia wartość satysfakcji z życia (SWLS) w grupie badanych $\mathrm{z}$ wykształceniem wyższym wynosiła 23,75 i była istotnie większa $(p=0,0001)$ od wynoszącej 20,97 w grupie ciężarnych z wykształceniem podstawowym/ zawodowym, oraz istotnie większa $(p=0,0001)$ od wynoszącej 21,17 w grupie badanych ciężarnych z wykształceniem średnim. Analiza porównawcza nie wykazała znamiennych różnic pomiędzy uzyskanymi wartościami średnimi $\mathrm{w}$ grupie kobiet $\mathrm{z}$ wykształceniem podstawowym lub zawodowym i średnim ( $\mathrm{p} \geq 0,05)$. Z badań wynika, że kobiety które miały wykształcenie wyższe odczuwały istotnie statystycznie lepszą satysfakcję z życia aniżeli kobiety $\mathrm{z}$ wykształceniem podstawowym lub zawodowym oraz średnim. Zatem wykształcenie było czynnikiem warunkującym satysfakcję z życia badanych. Ocena satysfakcji z życia kobiet ciężarnych w zależności od wykształcenia została przedstawiona $\mathrm{w}$ tabeli 4 .

Badania wykazały, że status zawodowy warunkował satysfakcję z życia badanych kobiet. Średnia wartość satysfakcji z życia (SWLS) w grupie badanych pracujących umysłowo wynosiła 23,81 i była istotnie większa od wynoszącej $20,55 \mathrm{w}$ grupie ciężarnych nie pracujących $(\mathrm{p}=0,0001)$. 


\section{Satysfakcja z życia kobiet ciężarnych}

Tab. 4. Współzależność pomiędzy satysfakcją z życia a wykształceniem badanych

\begin{tabular}{|c|c|c|c|c|c|c|c|c|c|c|c|}
\hline \multirow{3}{*}{ Analizowana zmienna } & \multicolumn{11}{|c|}{ Wykształcenie } \\
\hline & \multicolumn{3}{|c|}{ podstawowe / zawodowe } & \multicolumn{3}{|c|}{ średnie } & \multicolumn{3}{|c|}{ wyższe } & \multirow{2}{*}{$\mathbf{Z}$} & \multirow{2}{*}{$\mathbf{p}$} \\
\hline & $M$ & Me & SD & M & Me & SD & M & Me & SD & & \\
\hline Wskaźnik satysfakcji z życia & 20,97 & 22,00 & 6,42 & 21,17 & 22,00 & 5,45 & 23,75 & 24,00 & 5,53 & 19,737 & 0,0001 \\
\hline
\end{tabular}

Tab. 5. Wspótzależność pomiędzy satysfakcją żzycia a statusem zawodowym

\begin{tabular}{|c|c|c|c|c|c|c|c|c|c|c|c|c|c|c|}
\hline \multirow{3}{*}{ Analizowana zmienna } & \multicolumn{14}{|c|}{ Status zawodowy } \\
\hline & \multicolumn{3}{|c|}{ nie pracuje } & \multicolumn{3}{|c|}{ praca fizyczna } & \multicolumn{3}{|c|}{ praca umysłowa } & \multicolumn{3}{|c|}{ uczeń / student } & \multirow{2}{*}{$\mathbf{Z}$} & \multirow{2}{*}{$\mathbf{p}$} \\
\hline & M & Me & SD & M & Me & SD & M & Me & SD & M & Me & SD & & \\
\hline Wskaźnik satysfakcji z życia & 20,55 & 21,00 & 5,92 & 22,96 & 23,00 & 5,16 & 23,81 & 24,00 & 5,66 & 21,56 & 22,00 & 5,24 & 22,453 & 0,0001 \\
\hline
\end{tabular}

Analizę oceny satysfakcji z życia kobiet ciężarnych w zależności od statusu zawodowego przedstawiono w tabeli 5.

\section{DYSKUSJA}

Przedmiotem przedstawionej pracy było określenie poziomu satysfakcji z życia kobiet ciężarnych w zależności od czynników socjodemograficznych. Uzyskane wyniki badań własnych wykazały, że $48,43 \%$ badanych ciężarnych cechował wysoki stopień satysfakcji z życia, 35,18\% przeciętny, zaś $16,39 \%$ badanych - niski poziom satysfakcji z życia. Z badań przeprowadzonych w roku 2018 przez Centrum Badań Opinii Społecznej wynika, że 76\% Polaków deklaruje zadowolenie ze swojego życia [11].

$\mathrm{Na}$ podstawie przeprowadzonych badań własnych stwierdzono, że stan cywilny warunkuje zadowolenie z życia. Głębocka i Sarzyńska (2005), w badaniach przeprowadzonych w grupie osób starszych, dokonały oceny satysfakcji z życia zależnie od stanu cywilnego. Z badań Autorek wynika, że osoby posiadające małżonka były szczęśliwsze i prezentowały wyższy poziom satysfakcji z życia, aniżeli pozostali (kawalerowie, panny, wdowcy, wdowy, żyjący w związku nieformalnym) [12]. Podobne wyniki uzyskali Wysokiński i wsp. (2009), w badaniach przeprowadzonych w grupie pielęgniarek. $Z$ analizy badań tych Autorów wynika, że stan cywilny ma istotne znaczenie dla poziomu zadowolenia $\mathrm{z}$ życia. Najlepiej satysfakcję z życia oceniały osoby zamężne i owdowiałe. Osoby rozwiedzione oceniały poziom satysfakcji z życia, jako średni, zaś osoby stanu wolnego oceniły swój poziom satysfakcji z życia najgorzej [13]. Natomiast Kowalczyk i Rzepa (2015), poddając analizie 123 kobiety, w wieku od 20 do 60 lat wykazały, że kobiety pozostające w stałym związku odczuwały większą satysfakcję z życia aniżeli niepozostające w związku [14]. Kanadys i wsp. (2015), a także Kazimierczak i wsp. (2018) wykazali, że stan cywilny badanych warunkuje ich satysfakcję z życia, która była większa w grupie kobiet zamężnych, aniżeli samotnych $[15,16]$. Przeprowadzone badania własne pozostają w zgodności z badaniami powyższych Autorów. Z badań własnych wynika, że stan cywilny determinuje satysfakcję z życia badanych która jest istotnie większa w grupie ciężarnych będących w związku aniżeli w grupie kobiet samotnych $(\mathrm{p}<0,013)$.
W piśmiennictwie istnieją doniesienia wskazujące na zróżnicowanie poziomu satysfakcji z życia w zależności od wykształcenia badanych respondentów. Badania własne wykazały, że wykształcenie warunkuje satysfakcję z życia kobiet ciężarnych, która była wyższa w grupie kobiet z wykształceniem wyższym $(M=23,75)$, aniżeli w grupie badanych posiadających wykształcenie podstawowe lub zawodowe $(M=20,97)$, oraz średnie $(M=21,17)$.

Kanadys i wsp. (2015), na podstawie wyników badań własnych stwierdzili, iż kobiety ciężarne posiadające wykształcenie wyższe doświadczały wyższej satysfakcji z życia, aniżeli ciężarne $\mathrm{z}$ wykształceniem średnim, podstawowym lub zawodowym [15]. Ocena satysfakcji z życia wśród kobiet w wieku okołomenopauzalnym dokonana przez Kanadys i wsp. (2014), potwierdziła tezę, że wykształcenie warunkuje satysfakcję z życia, która była wyższa w grupie kobiet $\mathrm{z}$ wykształceniem wyższym aniżeli w grupie badanych posiadających wykształcenie średnie oraz podstawowe lub zawodowe [17].

Zadowolenie $\mathrm{z}$ posiadanego statusu zawodowego było kolejnym aspektem determinującym satysfakcję z życia badanych kobiet w ciąży. Przeprowadzone badania własne wykazały, że status zawodowy warunkuje satysfakcje z życia kobiet ciężarnych. Wartość średnia satysfakcji z życia (SWLS) w grupie badanych pracujących umysłowo wynosiła 23,81 i była istotnie większa $(\mathrm{p}=0,0001)$ od wynoszącej 20,55 w grupie ciężarnych niepracujących.

Według doniesień Centrum Badań Opinii Społecznej $\mathrm{z}$ roku 2017, 50\% respondentów było zadowolonych Z przebiegu swojej pracy zawodowej [11]. Badania Czarneckiej i wsp. (2012), oraz Banaczek i Saracen (2016), przeprowadzone wśród kobiet w okresie okołomenopauzalnym potwierdzają tezę, iż status zawodowy koreluje pozytywnie z wynikami satysfakcji z życia $[18,19]$. Podobne wyniki uzyskali Irfan i wsp. (2012) przeprowadzając badania wśród 90 kobiet w przedziale wiekowym od 25 do 36 lat. Osoby, które wyżej oceniały swój status zawodowy uzyskiwały wyższe wyniki w skali satysfakcji z życia [20].

\section{WNIOSKI}

Badana próba prezentowała wysoki poziom satysfakcji z życia. Stan cywilny, wykształcenie i status zawodowy $\mathrm{w}$ istotny sposób różnicują stopień zadowolenia z życia u kobiet ciężarnych. 


\section{REFERENCES/PIŚMIENNICTWO}

1. Juczyński Z. Narzędzia pomiaru w promocji i psychologii zdrowia. Pracownia Testów Psychologicznych Polskiego Towarzystwa Psychologicznego. Warszawa: 2012;128133.

2. Mazur A. Poczucie satysfakcji z życia osób o różnych stylach radzenia sobie ze stresem. Innowacje Psychologiczne. 2014; 4(1):1-8.

3. Byrd-Craven J, Massey AR. Lean on me: Effects of social support on low socioeconomic - status pregnant women. Nur Health Sci. 2013; 15:374-378.

4. Dyrdal GM, Røysamb E, Bang Nes R, et al. Can a happy relationship predict a happy life? A population-based study of maternal well-being during the life transition of pregnancy, infancy, and toddlerhood. J Happiness Stud. 2011; 12(6):947-962.

5. Dyrdal GM, Lucas RE. Reaction and adaptation to the birth of a child: a couple-level analysis. Dev Psychol. 2013; 49(4):749-761.

6. Aasheim V, Waldenström U, Rasmussen $S$, et al. Satisfaction with life during pregnancy and early motherhood in first-time mothers of advanced age: a population-based longitudinal study. BMC Pregnancy and Childbirth. 2014; 14:8695.

7. Gebuza G, Kaźmierczak M, Mieczkowska E, i wsp. Social support as a determinant of life satisfaction in pregnant women and women after surgical delivery. Psychiatr. Pol. 2018; 52(3): 585-598.

8. Chrzan-Dętkoś M. Psychodynamiczne rozumienie macierzyństwa-implikacje dla pracy klinicznej. Psychoterapia. 2010; 1(152):5-14.

9. Błaszczak A, Pilch D, Szamlewska B. Badanie poziomu lęku kwestionariuszem STAI C.D. Spielbergera u kobiet w okresie okołoporodowym. Perinatol Neonatol Ginekol. 2011; 4(3):163-168.

10. Gebuza G, Kaźmierczak M, Mieczkowska E, et al. Life satisfaction and social support received by women in the perinatal period. Adv Clin Exp Med. 2014; 23(4):611-619.

11. Badora B. Zadowolenie zżycia. Centrum Badań Opinii Społecznej. 2018; 3:1-17.

12. Głębocka A, Szarzyńska A. Wsparcie społeczne a jakość życia ludzi starszych. Gerontol Pol. 2005; 13(4):255-259.

13. Wysokiński M, Fidecki W, Walas L, i wsp. Satysfakcja z życia polskich pielęgniarek. Probl Pielęg. 2009; 17(3):167-172.

14. Kowalczyk J, Rzepa T. Konflikt ról rodzinnych i zawodowych a poczucie satysfakcji zżycia. Opuscula Sociologica. 2015; 2(12):67-76.

15. Kanadys K, Rogowska J, Lewicka M, i wsp. Satysfakcja z życia kobiet ciężarnych. Med Og Nauk Zdr. 2015; 21(1):45-48.

16. Kaźmierczak M, Gebuza G, Topolińska M, i wsp. Ocena stopnia satysfakcji z życia u kobiet ciężarnych. Piel Pol. 2018;67(1):22-27.

17. Kanadys K, Lewicka M, Sulima M, i wsp. Analiza poziomu satysfakcji z życia kobiet w okresie okołomenopauzalnym zależnie od wybranych czynników socjodemograficznych. Med 0g Nauk Zdr. 2014; 20(1):42-45.

18. Czarnecka-Iwańczuk M, Stanisławska-Kubiak M, Mojs E, i wsp. Objawy menopauzy a satysfakcja zżycia i samoocena wśród kobiet. Prz Menopauzalny. 2012; 6: 468-473.

19. Banaczek $Z$, Saracen A. Satysfakcja życia i samoocena wśród kobiet w okresie menopauzy. Wiad Lek. 2016; 69, 2 (cz. II), 174-179.

20. Irfan M, Kaur N, Panwar N, et al. A comparative study of working and non-working married women: Effect of Anxiety level on life satisfaction. Indian Journal of Psychology \& Mental Health. 2012; 6(2):169-178.
Manuscript received/Praca zgłoszona do czasopisma: 28.06.2019

Manuscript accepted/Praca zaakceptowana do druku: 12.11.2019

Translation/Tłumaczenie: Piotr Pflieger 